4. Kalidindi, S., Vecha, M., Kar, A. and Raychoudhury, T., Aluminum-cerium double-metal impregnated activated carbon: a novel composite for fluoride removal from aqueous solution. Water Sci. Technol.: Water Suppl., 2017, 17, 115-124.

5. Raychoudhury, T., Boindala, S. P. and Kalidindi, S., Performance evaluation of metal impregnated activated carbon composite for removal of fluoride under different solution chemistry. Water Sci. Technol.: Water Suppl., 2017, 17(5), 1377-1385.

6. Inanya, M. and Raychoudhury, T., Application of activated carbon-metal composite for fluoride removal from contaminated groundwater in India. Int. J. Environ. Sci. Technol., 2018; https://doi.org/10.1007/s13762-018-2097-9.

7. Tripathy, S. S., Bersillon, J. L. and Gopal, K., Removal of fluoride from drinking water by adsorption onto alum-impregnated activated alumina. Sep. Purif. Technol., 2006, 50, 310-317.

8. Kang, D., Yu, X. and Ge, M., Morphology-dependent properties and adsorption performance of $\mathrm{CeO}_{2}$ for fluoride removal. Chem. Eng. J., 2017, 330, 36-43.

9. Viswanathan, N. and Meenakshi, S., Enhanced and selective fluoride sorption on $\mathrm{Ce}$ (iii) encapsulated chitosan polymeric matrix. J. Appl. Polym. Sci., 2009, 112, 1114-1121.

10. Zhang, S., Lu, Y., Lin, X., Su, X. and Zhang, Y., Removal of fluoride from groundwater by adsorption onto $\mathrm{La}$ (iii)-Al(iii) loaded scoria adsorbent. Appl. Surf. Sci., 2014, 303, 1-5.

11. Guo, X. and Chen, F., Removal of arsenic by bead cellulose loaded with iron oxyhydroxide from groundwater. Environ. Sci. Technol., 2005, 39, 6808-6818.

12. Yu, Y., Yu, L. and Chen, J. P., Adsorption of fluoride by $\mathrm{Fe}-\mathrm{Mg}$ La triple-metal composite: adsorbent preparation, illustration of performance and study of mechanisms. Chem. Eng. J., 2015, 262, 839-846.

13. Fiol, N. and Villaescusa, I., Determination of sorbent point zero charge: usefulness in sorption studies. Environ. Chem. Lett., 2009, 7, 79-84.

14. Koilraj, P. and Kannan, S., Aqueous fluoride removal using $\mathrm{ZnCr}$ layered double hydroxides and their polymeric composites: batch and column studies. Chem. Eng. J., 2013, 234, 406-415.

15. Alagumuthu, G. and Rajan, M., Equilibrium and kinetics of adsorption of fluoride onto zirconium impregnated cashew nut shell carbon. Chem. Eng. J., 2010, 158, 451-457.

16. Ma, Y., Wang, S.-G., Fan, M., Gong, W.-X. and Gao, B.-Y., Characteristics and defluoridation performance of granular activated carbons coated with manganese oxides. J. Hazard Mater, 2009, 168, 1140-1146.

17. Liu, H., Deng, S., Li, Z., Yu, G. and Huang, J., Preparation of Al-Ce hybrid adsorbent and its application for defluoridation of drinking water. J. Hazard Mater, 2010, 179, 424-430.

18. Wang, J., Xu, W., Chen, L., Jia, Y., Wang, L., Huang, X.-J. and Liu, J., Excellent fluoride removal performance by $\mathrm{CeO}_{2}-\mathrm{ZrO}_{2}$ nanocages in water environment. Chem. Eng. J., 2013, 231, 198-205.

19. Bo, L., Ran, L., Quan-Jun, L., Ming-Guang, Y., Bo, Z., Tian, C., Bing-Bing, L. and Jing, L., Study of high pressure structural stability of $\mathrm{CeO}_{2}$ nanoparticles. Chin. Phys. C, 2013, 37, 098003.

ACKNOWLEDGEMENTS. We thank Dr Ramakrishna, Global Ecocarb Pvt Ltd, Bengaluru for providing the $\mathrm{AC}_{\mathrm{Eco}}$ samples. We also thank the Dr Abhas Singh (IIT Kanpur) and Sophisticated Analytical Instrument Facility (SAIF), Cochin for providing instrumentation facilities.

Received 16 July 2018; revised accepted 3 April 2019

\section{Evaluation of high rate MBBR to predict optimal design parameters for higher carbon and subsequent ammoniacal nitrogen removal}

\author{
Sandip Magdum ${ }^{1, *}$ and V. Kalyanraman ${ }^{2}$ \\ ${ }^{1}$ Department of Technology, Savitribai Phule Pune University, \\ Pune 411 007, India \\ ${ }^{2}$ COE Biotechnology, R.D. Aga Research, Technology and Innovation \\ Centre, Thermax Ltd, Pune 411 019, India
}

The high rate moving bed biofilm reactor (MBBR) processes were designed for wastewater treatment to meet the past effluent discharge norms of biological oxygen demand (BOD) $<50 \mathrm{mg} / \mathrm{l}$. However, they are incapable of meeting current effluent discharge norms which consist of BOD $<10 \mathrm{mg} / \mathrm{l}$ and total nitrogen $<10 \mathrm{mg} / \mathrm{l}$. This study analyses the effect and variation of organic loading rate from $1.21 \mathrm{~kg}$ to $4.59 \mathrm{~kg}$ chemical oxygen demand $(\mathrm{COD}) /\left(\mathrm{m}^{3}\right.$ day $)$ and surface loading rate from $4.9 \mathrm{~g}$ to $24 \mathrm{~g} \mathrm{COD} /\left(\mathrm{m}^{2}\right.$ day $)$ on a high rate MBBR performance. The results of $C O D$ reduction $\left(C O D_{\text {red }}\right)$ and subsequent ammoniacal nitrogen reduction $\left(\mathrm{NH}_{3}-\mathrm{N}_{\text {red }}\right)$ were in the range of $65.4 \%$ to $87.8 \%$ and $11.8 \%$ to $47.2 \%$ respectively. The projected graphical optimization defines the design parameters for $M B B R$ and also predicts $C O D_{\text {red }}$ and subsequent $\mathrm{NH}_{3}-\mathrm{N}_{\text {red }}$. By understanding this subsequent $\mathrm{NH}_{3}-\mathrm{N}_{\text {red }}$ in the MBBR system, future designs for engineering technologies will be aided.

Keywords: Graphically, HRT, MBBR, optimized, organic load, wastewater.

THE moving bed biofilm reactor (MBBR) technology is commonly known for its high rate wastewater treatment process. In the last decade of the 20th century, this process was studied with great interest, eventually developing in its own technological space. In the 'moving bed biofilm' process, a suspended, porous polymeric is used as a carrier which then moves continuously in the aeration tank, causing the active biomass to grow as a biofilm on the surface of the carrier ${ }^{1}$. In addition, more than $90 \%$ of the biomass is attached to the media rather than suspended in the liquid ${ }^{2}$. A number of these characteristics has made the MBBR process more acceptable in the current era. It is a complete mix, compact, with continuous flow through, has high stability against load variation, lower process head loss, and less reactor maintenance including air grid cleaning. There is no sludge recycling, and there is an easy retrofit for existing activated sludge process (ASP) plants with nitrifiers retention and high solids retention time (SRT). 
MBBR processing technology can sustain and effectively treat wastewater of varying organic load due to the self-modifying microbial characteristics of the biofilm. While effective, there are also some processing disadvantages such as, high operating costs, chemical requirements and dedication of large areas entirely to sludge separation and high sludge production ${ }^{3}$. Different combined schemes have been proposed to MBBR process to remove organics and nutrients from wastewater ${ }^{4}$. It is an attached growth (biofilm) process where the available surface area for microbial attachment is one of the designing parameters. Biophysical parameters such as 'provision of surface area for biofilm growth' also termed as 'specific area removal rate' $\left(\mathrm{kg}\right.$ substrate $/ \mathrm{m}^{2}$ reactor volume per day) or surface loading rate (SLR) and rate of biodegradability also termed as 'volumetric removal rate' (kg substrate $/ \mathrm{m}^{3}$ reactor volume per day) or organic loading rate (OLR), are studied as MBBR design parameters. The performance of the MBBR process depends on the percentage of media provided in the reactor ${ }^{5}$. A number of different carriers have been designed and developed for MBBR applications and are differentiated in terms of the types of material used (polyethylene/polypropylene), density $\left(0.9\right.$ to $\left.1 \mathrm{~g} / \mathrm{cm}^{3}\right)$, and the specific surface area (100 to $1000 \mathrm{~m}^{2} / \mathrm{m}^{3}$ ). Hydraulic retention time (HRT) decides the volume of the reactor and hence the foot print of the secondary process. Based on design data obtained from practical operations of various plants, it was demonstrated that the MBBR may be used in an extremely compact, high-rate process $(<1 \mathrm{~h}$ total HRT) for secondary treatment ${ }^{6}$.

Some of the industrial effluents, such as coking wastewater, was also successfully treated in this process (achieved chemical oxygen demand (COD) reduction $89 \%$ ) which was designed for $20 \mathrm{~h}$ of HRT with a $50 \%$ carrier filling ratio $^{7}$. For effective nitrogen removal, MBBR process was based on the modified LudzackEttinger configuration, resulting in higher HRT of 8-18 h (ref. 8). A recent study investigated the behaviour of nitrification in MBBR system which was subjected to high COD input with OLR up to $3.2 \mathrm{~kg} \mathrm{COD} /\left(\mathrm{m}^{3}\right.$ day), whereas the MBBR performance which registered above $3.2 \mathrm{~kg}$ $\mathrm{COD} /\left(\mathrm{m}^{3}\right.$ day $)$ has not been assessed ${ }^{9}$.

In India, MBBR process is accepted, established, and has been in use over the last two decades. There are about 300 to $400 \mathrm{MBBR}$-based wastewater treatment plant installations found throughout the country ${ }^{10}$. MBBR plants vary from smaller, decentralized capacities of $10 \mathrm{~m}^{3} /$ day, to higher capacity sewage treatment plants of up to $20,000 \mathrm{~m}^{3} /$ day (ref. 11 ). Old Indian MBBR installations are designed for a high rate organic carbon removal process, with 2-3 h of HRT, with no focus on nitrogen removal. Although these processes are not designed for ammoniacal nitrogen removal, a parallel or subsequent reduction of ammoniacal nitrogen occurs on account of: (1) Microbial utilization for biological synthesis, and
(2) Conversion through slow rate nitrification. This subsequent nitrogen removal process in high rate MBBR has not been quantified and evaluated. This requires further detailed study and understanding to suitably apply the advantages of MBBR process in the existing and future wastewater treatment designs.

The aim of the present study is to evaluate various process parameters, viz. SLR, OLR, HRT and percent carrier media for maximum simultaneous COD and ammoniacal nitrogen removal in the old MBBR system, thus providing valuable results to further optimize the design conditions for complete nitrogen removal.

A MBBR is prepared by using two cylindrical tanks with a height and diameter of $310 \mathrm{~mm}$ and $250 \mathrm{~mm}$ respectively, and a 15.21 volume. Air grid and influent pipes are at the bottom of the reactor as shown in Figure 1. Air from the bottom of the reactor is supplied with a calculated flow rate of $1.8 \mathrm{~m}^{3} / \mathrm{h}$ to provide oxygen for biological activity of microbial mass, and also for fluidizing the carriers. Two separate peristaltic pumps (Make: Ravel Hitek) are used to feed the influent to both the reactors by maintaining their respective HRTs. Two sludge settlers of 5 litre volume are constructed downstream of the reactors for the purpose of solids separation from the effluent, as well as for the proposed sampling. Considering the range of flow rates studied here, HRT and OLRs varied in the ranges of $2-3 \mathrm{~h}$ and $1.21 \mathrm{~kg}$ to $4.59 \mathrm{~kg} \mathrm{COD} /\left(\mathrm{m}^{3}\right.$ day) respectively. In the present study, circular biofilm carriers were made of PE (polyethylene) plastic (density $0.94-0.96 \mathrm{~g} / \mathrm{cm}^{3}$ ) and were designed specially to provide protected surface areas for microbial biofilm to develop. This inner surface area protected the grown biofilm from shared forces generated by the carrier's movement. Carrier media used in this study offered a specific surface area of $500 \mathrm{~m}^{2} / \mathrm{m}^{3}$ (with an outer diameter of $19 \mathrm{~mm}$ and inner diameter of $17 \mathrm{~mm}$ ). The effects of variable carrier media filling/loading fraction from $30 \%$ to $60 \%$ volume/volume on MBBR performance was also evaluated in this study.

Synthetic wastewater is used as an influent source, which has biodegradable organic and inorganic pollutants such as glucose $\left(\mathrm{C}_{6} \mathrm{H}_{12} \mathrm{O}_{6}\right)$, ammonium chloride $\left(\mathrm{NH}_{4} \mathrm{Cl}\right)$, di-ammonium phosphate (DAP) and sodium bicarbonate $\left(\mathrm{NaHCO}_{3}\right)$. Every day fresh synthetic wastewater is prepared as a feed system to meet the targeted concentrations of COD $300 \pm 50 \mathrm{mg} / \mathrm{l}$, ammoniacal nitrogen $\left(\mathrm{NH}_{3}-\right.$ N) $40 \pm 5 \mathrm{mg} / 1$ and orthophosphate $\left(\mathrm{PO}_{4}-\mathrm{P}\right) 10 \pm 3 \mathrm{mg} / \mathrm{l}$.

Pilot experiments were performed in different operating conditions mentioned in Table 1 . Synthetic wastewater was prepared in the laboratory and used throughout the experiment, maintaining a constant contaminant's composition. The study included the effect of carrier filling rate, HRT, SLR and OLR on the performance of MBBR in terms of COD and $\mathrm{NH}_{3}-\mathrm{N}$ reduction (using $30 \%, 40 \%, 50 \%$ and $60 \%$ of carriers with HRTs of $2 \mathrm{~h}$ and $3 \mathrm{~h}$ duration). Plastic carrier media were acclimatized 


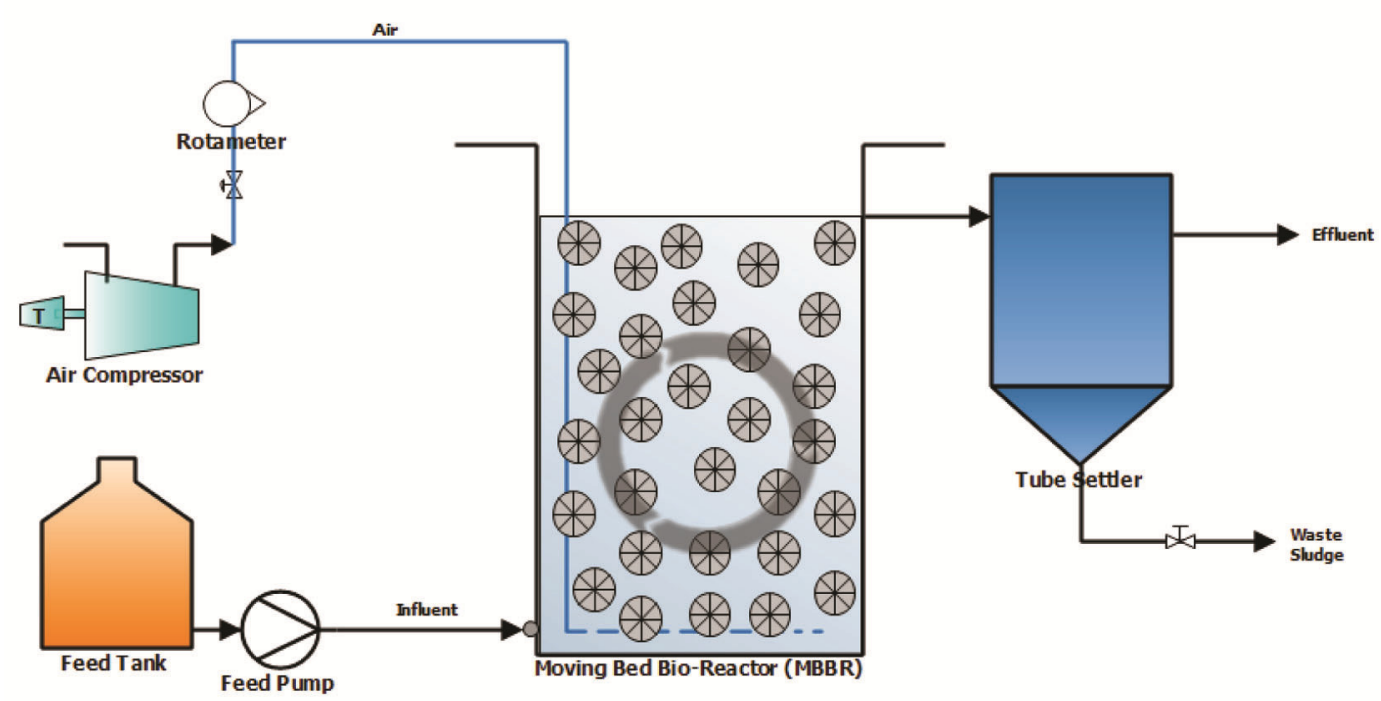

Figure 1. Laboratory setup of high rate moving bed biofilm reactor.

Table 1. Experimental moving bed biofilm reactor operating parameters with given respective organic loading rate (OLR) and surface loading rate (SLR)

\begin{tabular}{lcccc}
\hline Flow $(1 / \mathrm{h})$ & HRT $(\mathrm{h})$ & Media $(\%)$ & $\begin{array}{c}\text { Average OLR } \mathrm{kg} \\
\text { COD } /\left(\mathrm{m}^{3} \text { day }\right)\end{array}$ & $\begin{array}{c}\text { Average SLR } \\
\mathrm{g} \mathrm{COD} /\left(\mathrm{m}^{2} \text { day }\right)\end{array}$ \\
\hline 8.5 & 2 & 30 & 3.7 & 24.65 \\
& & 40 & 3.63 & 18.16 \\
& 50 & 3.32 & 13.27 \\
5.7 & 60 & 3.48 & 11.56 \\
& 3 & 30 & 1.56 & 10.4 \\
& & 40 & 2.02 & 10.09 \\
& 50 & 1.63 & 4.94 \\
\hline
\end{tabular}

COD, Chemical oxygen demand.

in the reactor by providing synthetic wastewater as feed to the system. This acclimatization of carriers lasted for three weeks. Respective sets of carriers were added to the reactors and samples collected every day for analysing total organic carbon (TOC), $\mathrm{COD}$ and $\mathrm{NH}_{3}-\mathrm{N}$. During this period, all the above mentioned conditions were monitored, and $\mathrm{pH}$ of the reactor was maintained at 7.0 \pm 0.5 using $\mathrm{NaHCO}_{3}$. The effect on $\mathrm{COD}$ and $\mathrm{NH}_{3}-\mathrm{N}$ reduction due to variation in percent carrier media and HRT was a targeted evaluation. Using these readings design parameters such as OLR and SLR were also analysed for their optimization.

During the experimental phase, samples of influents and effluents were collected and filtered with crude filter paper every day. These samples were analysed according to standard and methods ${ }^{12}$ protocols. TOC was analysed using TOC analyser (TOC-V CPH, Shimadzu Ltd), while COD was analysed by the APHA method, 5220B (potassium dichromate method), and the analysis of total organic nitrogen and $\mathrm{NH}_{3}-\mathrm{N}$ was done by titrimetric method described in the APHA method (number 4500- $\mathrm{NH}_{\text {org }} \mathrm{B}$ and $4500-\mathrm{NH}_{3} \mathrm{E}$ for all the samples). Finally, graphical method was applied to analyse the experimental readings and to find the optimized design parameters.

Experiments with lower HRT were performed to evaluate the higher rate aerobic oxidation of organics and nitrogen contaminants in the wastewater. HRT governs the reactor volume/sizing as well as influences the treatment efficiencies directly. Effects of $2 \mathrm{~h}$ and $3 \mathrm{~h}$ HRT experiments were evaluated for COD reduction $\left(\mathrm{COD}_{\text {red }}\right)$ and $\mathrm{NH}_{3}-\mathrm{N}$ reduction $\left(\mathrm{NH}_{3}-\mathrm{N}_{\text {red }}\right.$ ) (Figure 2). The average $\mathrm{COD}$ and $\mathrm{NH}_{3}-\mathrm{N}$ in the feed water was $294.3 \mathrm{mg} / \mathrm{l}$ and $41.1 \mathrm{mg} / 1$ respectively, during $2 \mathrm{~h}$ HRT experiments. The load increase of the carrier media from $30 \%$ to $60 \% \mathrm{v} / \mathrm{v}$ is also shown in Figure 2. The average output (treatment effluent) readings after $2 \mathrm{~h}$ aerobic oxidation treatment were $\mathrm{COD}_{\text {Out }} 67.5 \mathrm{mg} / 1\left(77.4 \% \mathrm{COD}_{\text {red }}\right)$ and $\mathrm{NH}_{3}-\mathrm{N}_{\text {Out }}$ $34.8 \mathrm{mg} / \mathrm{l}\left(15.4 \% \mathrm{NH}_{3}-\mathrm{N}_{\text {red }}\right.$ ) (Figure $2 a$ ). The analysis of COD and $\mathrm{NH}_{3}-\mathrm{N}$ reduction done for a $3 \mathrm{~h}$ of HRT shows the average $\mathrm{COD}_{\text {In }}$ and $\mathrm{NH}_{3}-\mathrm{N}_{\text {In }}$ to be $209.2 \mathrm{mg} / \mathrm{l}$ and 

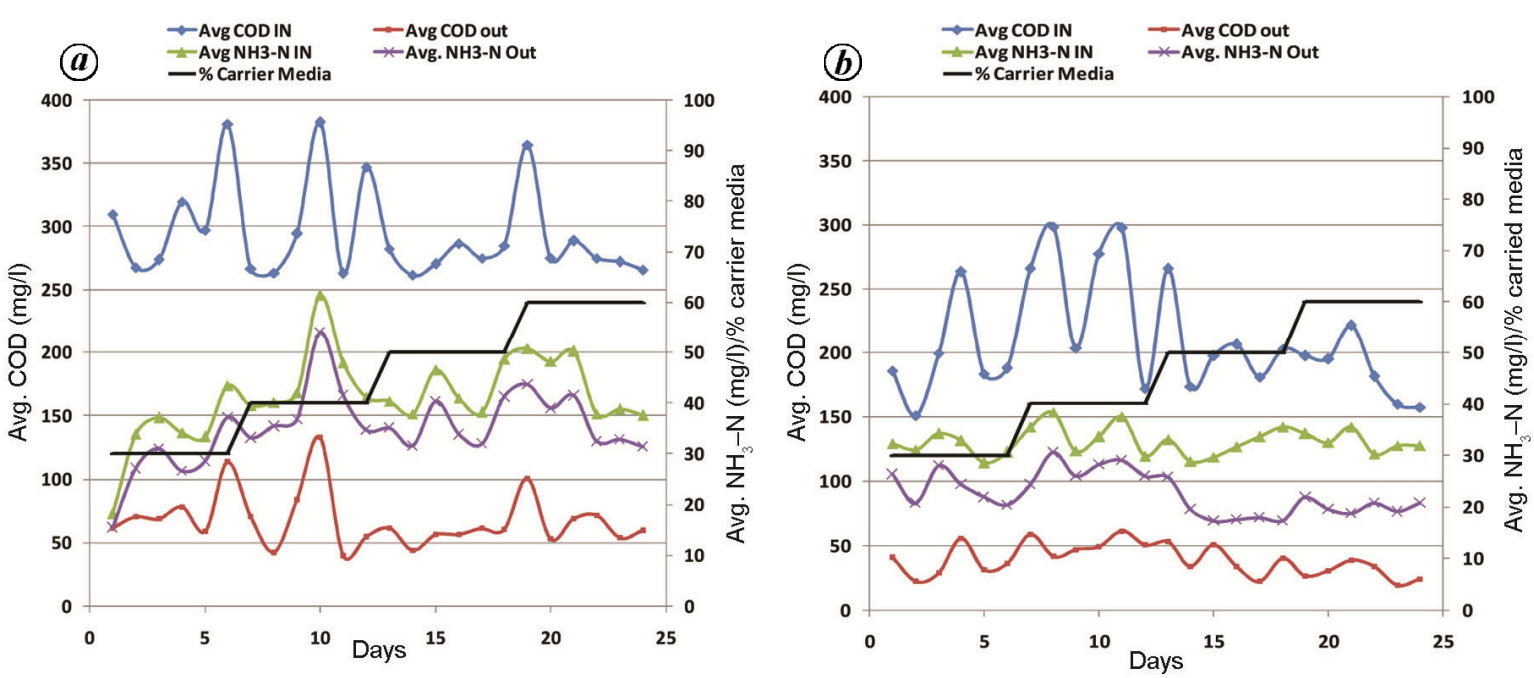

Figure 2. MBBR data analysis of chemical oxygen demand reduction $(\mathrm{COD})_{\text {red }}$ and ammonical nitrogen reduction $\left(\mathrm{NH}_{3}-\mathrm{N}_{\text {red }}\right)$. $\boldsymbol{a}, 2 \mathrm{~h}$ of hydraulic retention time (HRT) with different percent carrier media. $\boldsymbol{b}, 3 \mathrm{~h}$ of HRT with different percent carrier media.

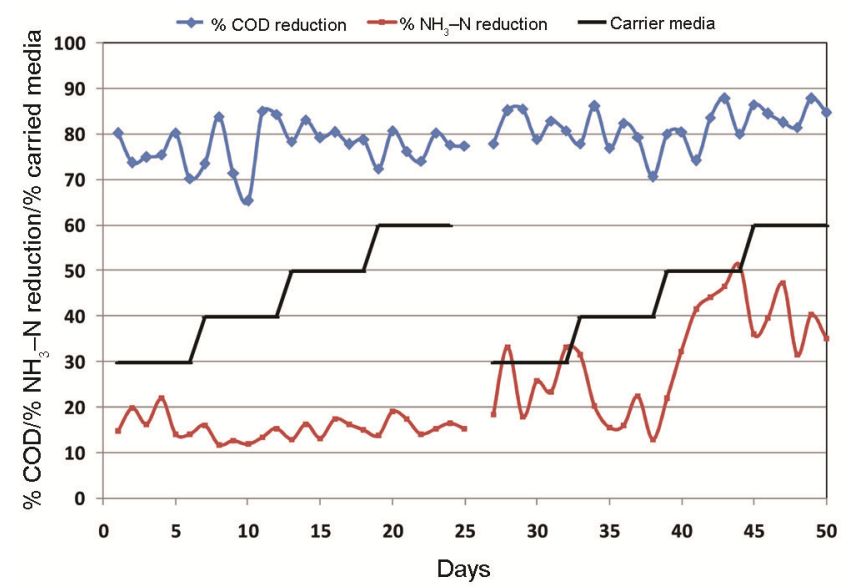

Figure 3. Effect of percent carrier media filling on percent $\mathrm{COD}_{\text {red }}$ and percent $\mathrm{NH}_{3}-\mathrm{N}_{\text {red }}$.

$32.6 \mathrm{mg} / 1$ respectively. The treated effluent of $3 \mathrm{~h}$ HRT trials was $\mathrm{COD}_{\text {out }} 38.7 \mathrm{mg} / \mathrm{l}$ (i.e. $81.6 \% \mathrm{COD}_{\text {red }}$ ) and $\mathrm{NH}_{3}-\mathrm{N}_{\text {out }} 22.6 \mathrm{mg} / \mathrm{l}$ (i.e. $30.8 \% \mathrm{NH}_{3}-\mathrm{N}_{\text {red }}$ ) (Figure $2 b$ ). The $3 \mathrm{~h}$ HRT process showed a higher $\mathrm{COD}$ and $\mathrm{NH}_{3}-\mathrm{N}$ removal than the $2 \mathrm{~h}$ process. Contrary to the above results, an earlier study reported that variation in higher HRT did not affect the COD and $\mathrm{NH}_{3}-\mathrm{N}$ removal efficiencies, but considerably influenced the organic-nitrogen removal and distribution of oxidized nitrogen in the final effluent ${ }^{13}$. Another study of septic tank effluent treatment using a moving bed biological reactor showed an increase in the rate of average ammonia removal from $0.279 \mathrm{~kg}$ to $0.540 \mathrm{~kg} \mathrm{~N} / \mathrm{m}^{3}$ when the reactor's HRT changed from 5.7 to $13.3 \mathrm{~h}$ (ref. 14). Figure 2 also shows the variation in $\mathrm{v} / \mathrm{v}$ percent carrier media loading during experimentation with respect to input/output treatment values. However, mere observation of the graph does not show its significance.
Due to variations in inlet and outlet concentrations of COD and $\mathrm{NH}_{3}-\mathrm{N}$, significance of the percentage of carrier media variation on treatment efficiency is not clearly observed in Figure 2. Figure 3 shows the effect of percent carrier media on $\mathrm{COD}_{\text {red }}$ and $\mathrm{NH}_{3}-\mathrm{N}_{\text {red }}$ percentages, distinctly. Results of $2 \mathrm{~h} \mathrm{HRT} \mathrm{did} \mathrm{not} \mathrm{show} \mathrm{much} \mathrm{difference}$ in the treatment efficiencies influenced by variation in percent carrier media (i.e. surface area). At 30\% (lower) and $60 \%$ (higher) $\mathrm{v} / \mathrm{v}$ carrier media loading, the reactor showed $75.8 \%$ and $76.9 \%$ of average $\mathrm{COD}_{\text {red, }}$ and $16.9 \%$ and $16.1 \%$ average $\mathrm{NH}_{3}-\mathrm{N}_{\text {red }}$ respectively. However, $3 \mathrm{~h}$ HRT trials with $30 \%$ and $60 \% \mathrm{v} / \mathrm{v}$ carrier media loading showed $81.8 \%$ and $84.6 \%$ average $\mathrm{COD}_{\text {red }}$, and $25.3 \%$ and $38.3 \%$ average $\mathrm{NH}_{3}-\mathrm{N}_{\text {red }}$ respectively (Figure 3). There is a marginal enhancement due to higher percentage media loadings. At lower HRT (or higher loading rate), variation in percentage of the carrier media loading did not show any major effect on degradation efficiencies.

According to a study carried out on MBBR with polyethylene $(\mathrm{PE})$ carriers, the filling rates were 10\%, 20\%, $30 \%$ and $40 \%$, while the average COD removal efficiency was at $75.7 \%, 91.1 \%, 85.5 \%$ and $79.6 \%$ respectively ${ }^{15}$. These results also showed that the MBBR system achieved higher COD removal efficiency at 20\% PE carrier filling rate under the same conditions of influent organic loading rates. Another study of COD polishing by using MBBR showed that the average removal rate of $41.75 \%$, $32.85 \%, 24.80 \%$ and $35.77 \%$ of initial COD were achieved under HRT of $24 \mathrm{~h}, 12 \mathrm{~h}, 6 \mathrm{~h}$ and $2 \mathrm{~h}$ respectively ${ }^{16}$.

Thus higher HRT shows higher degradation, but it is not linear as the system reduces HRT to just $2 \mathrm{~h}$. This validates similar results shown in the present study. Not much difference was observed in $\mathrm{COD}_{\text {red }}$ for $2 \mathrm{~h}$ and $3 \mathrm{~h}$ HRTs, and variation in carrier media filling, whereas, 

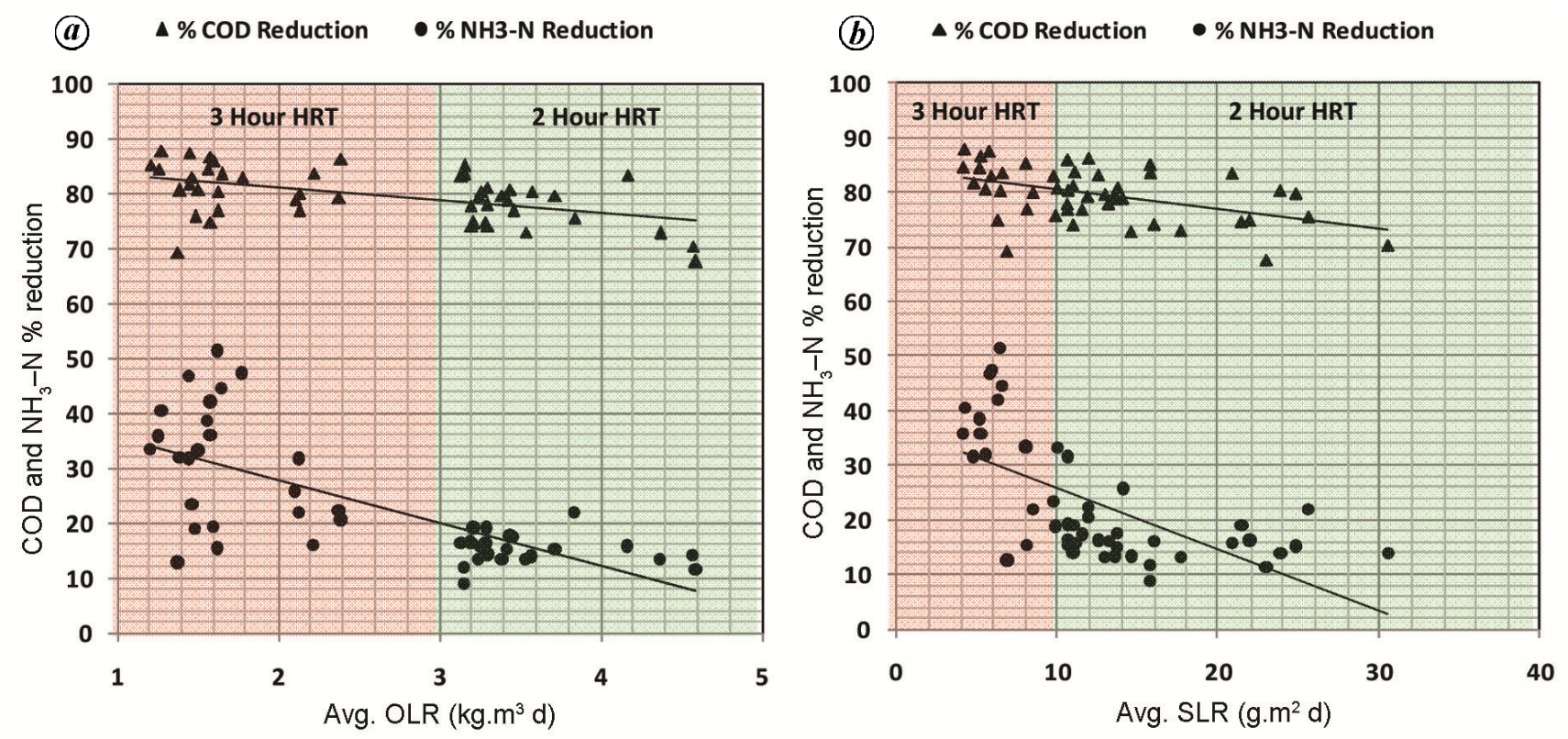

Figure 4. (a) Organic loading rate, (b) surface loading rate dependent outcome of $2 \mathrm{~h}$ and $3 \mathrm{~h} \mathrm{HRT}$ for $\mathrm{COD}_{\text {red }}$ and $\mathrm{NH}_{3}-\mathrm{N}_{\text {red }}$ percentage.

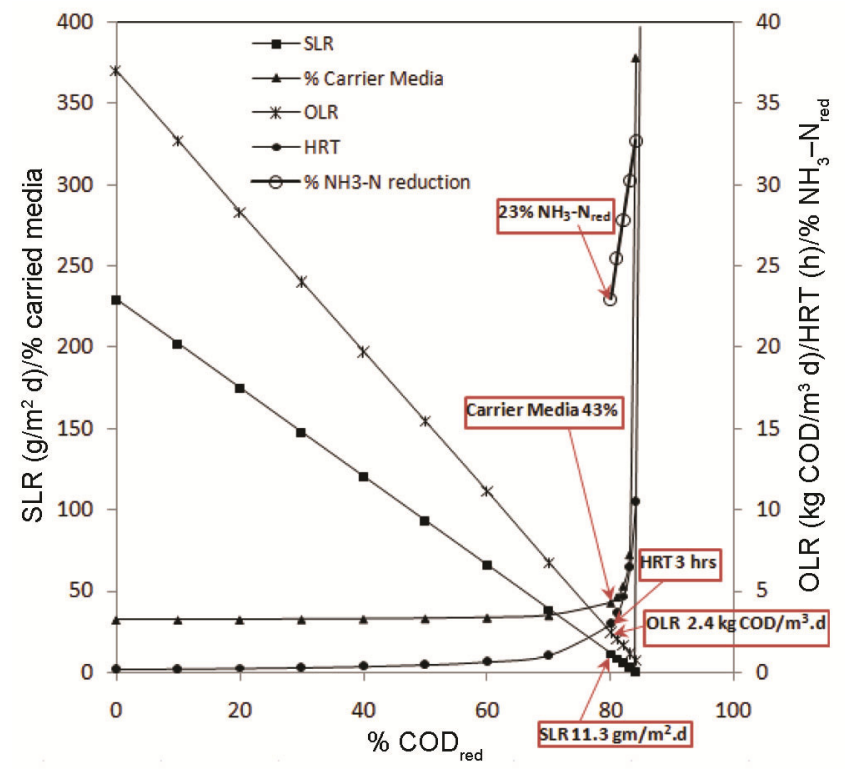

Figure 5. Interaction and selection of optimized MBBR design parameters for higher $\mathrm{COD}_{\text {red }}$ and $\mathrm{NH}_{3}-\mathrm{N}_{\text {red }}$.

there was notable effect on $\mathrm{NH}_{3}-\mathrm{N}_{\text {red }}$. As the HRT and percent carrier filling increases, there was an increase in $\mathrm{NH}_{3}-\mathrm{N}_{\text {red }}$ due to higher reaction time and more available surface area for nitrification. This study was performed at a wastewater temperature of $20^{\circ} \pm 2^{\circ} \mathrm{C}$, whereas at lower temperatures the rate of $\mathrm{COD}_{\text {red }}$ and $\mathrm{NH}_{3}-\mathrm{N}_{\text {red }}$ would drastically reduce ${ }^{17}$. Hence, the MBBR system always needs to be designed based on lower wastewater temperatures to achieve the desired effluent quality, as well as to cater to the negative performance effects of seasonal variation.

Experimental data obtained in this study was plotted to analyse the effects of varying OLR and SLR on percent $\mathrm{COD}_{\text {red }}$ and percent $\mathrm{NH}_{3}-\mathrm{N}_{\text {red. }}$. Figure $4 a$ shows that the high OLR received by the system of $2 \mathrm{~h}$ HRT trials, which was in the range of $3.14 \mathrm{~kg}$ to $4.59 \mathrm{~kg} \mathrm{COD} /$ $\left(\mathrm{m}^{3}\right.$ day) with an average value of $3.53 \mathrm{~kg} \mathrm{COD} /\left(\mathrm{m}^{3}\right.$ day $)$, showed an average $77.66 \%$ of $\mathrm{COD}_{\text {red }}$ and $15.24 \%$ of $\mathrm{NH}_{3}-\mathrm{N}_{\text {red. }}$. The trials of $3 \mathrm{~h}$ HRT operated at an OLR range of $1.21 \mathrm{~kg}$ to $2.39 \mathrm{~kg} \mathrm{COD} /\left(\mathrm{m}^{3}\right.$ day $)$ with an average value of $1.67 \mathrm{~kg} /\left(\mathrm{m}^{3}\right.$ day), showed an average $81.47 \%$ of $\mathrm{COD}_{\text {red }}$ and $30.78 \%$ of $\mathrm{NH}_{3}-\mathrm{N}_{\text {red }}$. Similarly, SLR values were also analysed for per cent $\mathrm{COD}_{\text {red }}$ and percent $\mathrm{NH}_{3}-\mathrm{N}_{\text {red }}$. The SLR of $2 \mathrm{~h}$ HRT trials varied from $24.7 \mathrm{~g} / \mathrm{m}^{2} \mathrm{~d}$ to $11.6 \mathrm{~g} /\left(\mathrm{m}^{2}\right.$ day $)$ with an observed average $\mathrm{COD}_{\text {red }}$ ranging from $75.9 \%$ to $79.9 \%$, and average $\mathrm{NH}_{3}-\mathrm{N}_{\text {red }}$ from $12.9 \%$ to $16.8 \%$ (Figure $4 b$ ). Similar SLR analysis for $3 \mathrm{~h} \mathrm{HRT}$ trials showed the average $\mathrm{COD}_{\text {red }}$ in the range of $78.6 \%$ to $84.6 \%$, and average $\mathrm{NH}_{3}-\mathrm{N}_{\text {red }}$ in the range of $19.7 \%$ to $39.7 \%$ with varied SLR from $10.4 \mathrm{~g}$ to $4.9 \mathrm{~g} \mathrm{COD} /\left(\mathrm{m}^{2}\right.$ day $)$. A MBBR study carried out by Melin et al. ${ }^{18}$, kept the HRTs range between $45 \mathrm{~min}$ and $4 \mathrm{~h}$, and the COD loading rates (SLR) between $4.1 \mathrm{~g}$ and $26.6 \mathrm{~g} \mathrm{COD} /\left(\mathrm{m}^{2}\right.$ day $)$. It showed that the average COD removal efficiencies in the total process were $87 \%$ at $3-$ $4 \mathrm{~h}$ HRTs, and $83 \%$ at $0.75-1 \mathrm{~h}$ HRT with relatively small observed differences in the removal efficiencies at different loading rates in MBBR. These results validate the present study's outcome which indicates that the wastewater treatment efficiency is non-linearly proportional to lower range HRTs. A similar MBBR study was 
done with SLR in the range of 3.6-17.37 $\mathrm{g} \mathrm{COD} /\left(\mathrm{m}^{2}\right.$ day $)$ and OLR in the range of $0.8-4.2 \mathrm{~kg} \mathrm{COD} /\left(\mathrm{m}^{3}\right.$ day $)$ which showed high COD removal efficiency in case of organic loading in the range of $87.3-98.8 \%$ (ref. 8). Further, the overall experimental data was analysed graphically to predict $\mathrm{COD}_{\text {red }}$ and $\mathrm{NH}_{3}-\mathrm{N}_{\text {red }}$ performance which depended on the selected design parameters.

Performance equations from the above graphs (Figure 4) were used to optimize the reactor sizing using a graphical method. Figure 5 shows that the studied high rate MBBR has a technological limitation of maximum $\mathrm{COD}_{\text {red }}$ up to $84 \%$ and maximum $\mathrm{NH}_{3}-\mathrm{N}_{\text {red }}$ up to $33 \%$. This data could be used to select desired design parameters and predict the respective percentage reductions of $\mathrm{COD}$ and $\mathrm{NH}_{3}-\mathrm{N}$ or vice-versa. In this case, the total optimized graphical results was used to design a process which was predicted to give $80 \%$ of $\mathrm{COD}_{\text {red }}$ and $23 \%$ of $\mathrm{NH}_{3}-\mathrm{N}_{\text {red }}$ with respective design parameters consisting of OLR of $2.4 \mathrm{~kg} \mathrm{COD} /\left(\mathrm{m}^{3}\right.$ day $)$, SLR of $11.3 \mathrm{~g} \mathrm{COD/}$ $\left(\mathrm{m}^{2}\right.$ day) and HRT of $3 \mathrm{~h}$, with $43 \%$ of carrier media loading.

Lowering the SLR in high rate MBBR has shown an enhancing effect on nitrification, but no major effect was observed on the COD oxidation process. Non-linear relationships between design's HRT (OLR) and design's percent carrier media loadings (SLR) have shown measured amount of contaminants removal in high rate MBBR processes. Graphical optimization of design parameters (SLR, OLR, HRT and percent carriers) could be applied effectively to select optimum parameters to design efficient and predictable MBBR processes. Studying and understanding this high rate degradation could be further applied to design complete nitrogen removal processes with the aid of extended nitrification and anoxic de-nitrification.

1. Loukidou, M. X. and Zouboulis, A. I., Comparison of two biological treatment processes using attached-growth biomass for sanitary landfill leachate treatment. Environ. Pollut., 2001, 111, 273-281.

2. Schmidt, T. M. and Schaechter, M., Topics in Ecological and Environmental Microbiology, Elsevier/Academic Press, Amsterdam, Boston, 2012.

3. Magdum, S. S. and Kalyanraman, V., Existing biological nitrogen removal processes and current scope of advancement. Res. J. Chem. Environ., 2017, 21, 43-53.

4. Ødegaard, H., Gisvold, B. and Strickland, J., The influence of carrier size and shape in the moving bed biofilm process. Water Sci. Technol., 2000, 41, 383-391.

5. Barwal, A. and Chaudhary, R., To study the performance of biocarriers in moving bed biofilm reactor (MBBR) technology and kinetics of biofilm for retrofitting the existing aerobic treatment systems: a review. Rev. Environ. Sci. Bio/Technol., 2014, 13, 285 299.

6. Odegaard, H., Innovations in wastewater treatment: the moving bed biofilm process. Water Sci. Technol., 2006, 53, 17-33.

7. Gu, Q., Sun, T., Wu, G., Li, M. and Qiu, W., Influence of carrier filling ratio on the performance of moving bed biofilm reactor in treating coking wastewater. Bioresour. Technol., 2014, 166, 7278.

8. Torkaman, M., Borghei, S. M., Tahmasebian, S. and Andalibi, M. R., Nitrogen removal from high organic loading wastewater in modified Ludzack-Ettinger configuration MBBR system. Water Sci. Technol., 2015, 72, 1274-1282.

9. Bassin, J. P., Dias, I. N., Cao, S. M. S., Senra, E., Laranjeira, Y. and Dezotti, M., Effect of increasing organic loading rates on the performance of moving-bed biofilm reactors filled with different support media: Assessing the activity of suspended and attached biomass fractions. Process Saf. Environ. Prot., 2016, 100, 131141.

10. Joshi, S., MBBR. Shrishti Eco-Research Institute, 2015; https:// sswm.info/step-nawatech/module-1-nawatech-basics/appropriate-technologies-0/mbbr (accessed on 30 January 2019).

11. CPCB, Inventorization of Sewage Treatment Plant, Delhi, 2015; https://nrcd.nic.in/writereaddata/FileUpload/NewItem 210 Inventorization_of_Sewage-Treatment_Plant.pdf (accessed on 17 June 2017).

12. APHA, Standard Methods for the Examination of Water and Wastewater, American Water Works Association/American Public Works Association/Water Environment Federation, 2012, 22nd edn.

13. Li, Y. M., Gu, G. W., Zhao, J. F., Yu, H. Q., Qiu, Y. L. and Peng, Y. Z., Treatment of coke-plant wastewater by biofilm systems for removal of organic compounds and nitrogen. Chemosphere, 2003, 52, 997-1005.

14. Almomani, F. A. and Khraisheh, M. A. M., Treatment of septic tank effluent using moving-bed biological reactor: kinetic and biofilm morphology. Int. J. Environ. Sci. Technol., 2016, 13, 1917-1932.

15. Shrestha, A., Specific Moving Bed Biofilm Reactor in Nutrient Removal from Municipal Wastewater, Master thesis, University of Technology, Sydney, Australia, 2013.

16. Kawan, J. A., Abd-Rahman, R., bin Jaafar, O. and Suja, F., Polishing of chemical oxygen demand (COD) using moving bed bio-reactor. Appl. Mech. Mater., 2015, 773-774, 1281-1285.

17. Almomani, F. A., Delatolla, R. and Örmeci, B., Field study of moving bed biofilm reactor technology for post-treatment of wastewater lagoon effluent at $1^{\circ} \mathrm{C}$. Environ. Technol., 2014, 35, 1596-1604.

18. Melin, E., Leiknes, T., Helness, H., Rasmussen, V. and Odegaard, H., Effect of organic loading rate on a wastewater treatment process combining moving bed biofilm and membrane reactors. Water Sci. Technol., 2005, 51, 421-430.

Received 7 November 2017; revised accepted 1 April 2019

doi: $10.18520 / \mathrm{cs} / \mathrm{v} 116 / \mathrm{i} 12 / 2083-2088$ 